\title{
Internal Control System Affects the Quality of Financial Report Information Palembang City Government
}

\author{
Rita Martini ${ }^{1, *}$ Fildzah Rahmah Satirah ${ }^{1}$ Nurhasanah Nurhasanah ${ }^{1}$ \\ Amelia Agustia Riskya Saputri ${ }^{1}$ \\ ${ }^{1}$ Accounting Department, Polytechnic State of Sriwijaya, Palembang 30139, Indonesia \\ ${ }^{2}$ Trade Department, Politeknik Mukah, Sarawak, Malaysia \\ *Corresponding author. Email: ritamartini@polsri.ac.id
}

Kartini binti Che Ibrahim ${ }^{2}$ Kartika Rachman Sari ${ }^{1}$ Endah Widyastuti ${ }^{1}$ Farida Husin ${ }^{1}$

\begin{abstract}
This study aims to find out the influence of the internal control system on the quality of financial statements on the Regional Secretary of Palembang City. Primary data was collected from 60 (sixty) questionnaires, all of which were returned. Respondents included staff in 12 (twelve) sections of the Palembang City Regional Secretariat. The analysis method applied is linear regression. The results of the study concluded that the internal control system has a positive and significant effect on the quality of financial statement information.
\end{abstract}

Keywords: Financial information, internal control, government accounting

\section{INTRODUCTION}

Financial statements are the result of the process of identifying, measuring, and recording economic transactions (financial) of government entities that serve as information in order to account for regional financial management of economic decision-making by external parties to local government entities that require it. Government financial statements are useful to provide information for stakeholders that can be used as a consideration for decision making and policy. Information will be useful if the information is understood and used by users and users trust the information. Financial information should be useful to the user just as the information must have value [1]. One form of accountability for local government financial management is to submit local government financial statements (LKPD). LKPD is structured to provide relevant information regarding the financial position and all transactions conducted by local governments during a reporting period [2] and [3].

A factor that can improve the quality of government financial statement information is the internal control system (SPI). Government Regulation No. 60 of 2008 on Internal Government Control System (SPIP) [4], states that SPIP is an SPI that is held thoroughly in the central government and local government. The goal is to achieve effective, efficient, transparent and accountable management of state finances, ministers/heads of institutions, governors, and regents/mayors must exercise control over the implementation of government activities [5]. Control over the implementation of government activities is carried out in the guidance of the SPIP. SPIP [4] aims to provide adequate confidence for the achievement of effectiveness and efficiency in achieving the objectives of state governance, reliability of financial reporting, security of state assets, and compliance with laws and regulations.

Based on data from the CPC the problem is still administrated by the weak SPI in the central or regional government [5]. There are still so many found noncompliance of employees or managers in SPI in companies or local governments. Similarly, the financial management of the area is still very lacking. This makes the quality of financial statements also decrease and can also have an impact on reliability and punctuality to financial statements [1] and [5]. There are still many irregularities that occur when auditors and CPC check a company's financial statements or in local governments [6], [7] and [8]. 


\section{LITERATURE REVIEW RESEARCH HYPOTHESES}

\subsection{Quality of Financial Statement Information}

Government Accounting Standart (SAP) Statement No.1 describes the definition of a financial statement as a structured report on the financial position and transactions made by a reporting entity [9]. Financial statements are one of the factors that describe the performance of an area. Government Regulation No. 71 of 2010 on SAP [9], financial statements are prepared to provide relevant information about the financial position and all transactions conducted by a reporting entity during a reporting period. Financial statements are primarily used to determine the value of economic resources utilized to carry out government operations, assess financial conditions, evaluate the effectiveness and efficiency of a reporting entity, and help determine its compliance with laws and regulations.

Quality information is information that has accuracy, speed and conformity to the needs of management and completeness of the information produced [1] [2]. The quality of financial statements is a normative requirement that must be met in the preparation of financial statements so that the resulting financial statements can provide useful information for users of these financial statements. Qualitative characteristics of financial statements are normative measures that need to be realized in accounting information so as to meet their goals. The following four characteristics are normative prerequisites needed so that government financial statements can meet the financially desired qualities contained in [9], which are relevant, reliable, comparable and understandable.

\section{$2.2 \mathrm{SPI}$}

SPI [4] as an integral process of actions and activities carried out continuously by the leadership and all employees to provide adequate confidence in the achievement of organizational goals through effective and efficient activities, reliability of financial reporting, security of state assets, and compliance with laws and regulations. Internal control is a process of achieving certain goals carried out by people from every level of the organization who are expected to be able to provide adequate confidence to achieve the interrelated goals between financial reporting, compliance and operations [4]. Internal control is a system/procedure that exists in an organization to maintain the process of operating activities in accordance with the policies that have been set for the achievement of the organization's own goals. Internal control contains organizational plans and methods used to maintain or protect assets and produce accurate and trustworthy information [5]. To achieve effective, efficient, transparent, and accountable management of state finances, ministers/heads of institutions, governors, and regents/mayors must exercise control over the implementation of government activities.

SPIP [4] consists of several elements, first, a control environment. Government Agency Leaders are obliged to create and maintain a control environment that causes positive behavior and is conducive to the application of SPI in their work environment. Such activities through the enforcement of integrity and ethical values; commitment to competence; conducive leadership; the establishment of an organizational structure that suits the needs; delegation of appropriate authority and responsibility; the preparation and implementation of sound policies on human resource development; embodiment of the role of an effective government internal surveillance apparatus; and good working relationships with relevant Government Agencies.

The second element of internal control is risk assessment. Risk assessment begins with the determination of the intentions and objectives of government agencies that are clear and consistent both at the agency level and at the level of activity. Furthermore, government agencies identify efficiently and effectively risks that can hinder the achievement of these goals, both sourced from within and outside the agency. The risks that have been identified are analyzed to determine their effect on goal achievement. Government Agency leaders formulate risk management approaches and risk control activities needed to minimize risk.

Internal control activities are policies and procedures [4] that can help ensure the implementation of government agency leadership directives to reduce the risks that have been identified during the risk assessment process. Government agencies must have relevant and reliable information on both financial and non-financial information, relating to external and internal events. Such information shall be recorded and communicated to the leadership and others in all Government Agencies that require it in the form and within the time frame, allowing the concerned to exercise internal control and operational responsibilities [5].

SPI monitoring is carried out through continuous monitoring, separate evaluation, and follow-up recommendations of audit results and other reviu [4]. Continuous monitoring is organized through routine management activities, supervision, benchmarking, reconciliation, and other related actions in the 
implementation of tasks. Separate evaluations are organized through self-assessment, reviu, and testing of the effectiveness of SPI that can be carried out by the government's internal supervision apparatus or external government parties using a list of internal control tests.

Based on the problems that have been proposed before, the following hypotheses can be formulated:

SPI affects the quality of financial statement information at the Regional Secretariat of Palembang City.

\section{RESEARCH METHODOLOGY}

The population in this study is the Regional Secretariat of Palembang city which consists of 12 parts. The sampling technique in this study uses nonprobability sampling methods with a purposive sampling approach, which is a data source sampling technique with certain considerations. Considerations that have work responsibilities and are directly involved in making financial statements [1]. Where the overall sample taken is as many as 5 respondents consisting of The Head of Section, 3 Sub-Section Heads, Auxiliary Treasurers multiplied by 12 sections in the Regional Secretariat of Palembang City, namely 60 respondents who were given research questionnaires.

The independent variable in the study was SPI (X). The SPI referred to in this research is an integral process in the actions and activities carried out continuously by the leadership and all employees to provide adequate confidence in the achievement of organizational goals through effective and efficient activities, reliability of financial reporting, security of state assets, and compliance with laws and regulations.

Dependent variables are variables that are affected or that are consequent, because of the existence of free variables. The dependent variable in the study was the quality of local government financial statement (Y) information. The quality of local government financial statement information referred to in this study is based on the qualitative characteristics of financial statements contained in [9]. The measurement scale used in this study is the interval scale because there is a scale size from 1 to 5 . While the measurement technique is summated rating method: Likert Scale or Likert Scale.

The analytical technique used in this study is a Simple Linear Regression Analysis method to obtain an overview of the influence of independent and dependent variables. First, data quality testing is done with validity, reliability, and t test tests.

\section{RESULT AND DISCUSSION}

\subsection{Result}

The results of the One Sample Kolmogorov-Smirnov Test showed that the residual probability value $\left(\mathrm{p}_{\text {value }}\right)$ in the study had a value greater than 0.05 , which was 0.200 . This means that residual data is normally distributed. The tolerance value for each variable is greater than 0.1 and the VIF value is less than 10 so it can be stated that there is no multicollinearity problem in this researchmodel. The results of the hetericedity test obtained no single statistically significant independent variable affecting the residual absolutevalue dependentvariable. This is evident from the probability of its significance above the confidence level of 0.05 , thus indicating that the regression model does not occur heteroskedasticity.

In this study, hypotheses were tested using a simple linear regression model, to obtain a thorough overview of the effect of SPI variables on the quality of financial statement information. The test results are presented in Table 1.

Table 1. Linear Regression Analysis Test Results

\begin{tabular}{|c|c|c|c|c|c|c|}
\hline \multicolumn{7}{|c|}{ Coefficients $^{\mathrm{a}}$} \\
\hline \multirow{2}{*}{\multicolumn{2}{|c|}{ Model }} & \multicolumn{2}{|c|}{ Unstandardized Coefficients } & \multirow{2}{*}{$\begin{array}{c}\text { Standardized Coefficients } \\
\text { Beta }\end{array}$} & \multirow[b]{2}{*}{$\mathrm{t}$} & \multirow[b]{2}{*}{ Sig. } \\
\hline & & B & Std. Error & & & \\
\hline \multirow[t]{2}{*}{1} & (Constant) & 2.960 & 2.971 & & .996 & .323 \\
\hline & $\mathrm{X}$ & .123 & .053 & .145 & 2.346 & .023 \\
\hline
\end{tabular}

Source: SPSS data, 2021.

Based on SPSS output, data analysis models can be formulated in this study through the equation:

$\mathrm{Y}=2,960+0,145 \mathrm{SPI}+\mathrm{e}$
The explanation of the equation above is as follows:

1. The constant value (a) of this equation is worth 2,960 explaining that the average value on the 
quality of financial statement information at the SPI is constant or equal to 2,960 .

2. Coefficient value $\left(b_{1}\right)$ of 0,145

This regression equation model has a positive coefficient value of 0.145 . The figure of 0.145 means that any increase in SPI will increase the quality of financial statement information by 0.145 assuming that other independent variables are fixed in value.

\subsubsection{Research Instrument Test}

The results of the analysis in Table 2 show that all question items for internal control system variables have valid criteria. Valid/viable questionnaire items will be used as research instruments, as the $r_{\text {count }}$ is larger when compared to the $r_{\text {table }}$

Table 2. SPI Variable Validity Test Results

\begin{tabular}{|c|c|c|c|}
\hline $\begin{array}{c}\text { Question } \\
\text { Item }\end{array}$ & $\mathrm{r}_{\text {count }}$ & $\mathrm{r}_{\text {table }}$ & Information \\
\hline SPI1 & 0,935 & 0.254 & valid \\
\hline SPI2 & 0,955 & 0.254 & valid \\
\hline SPI3 & 0,955 & 0.254 & valid \\
\hline SPI4 & 0,853 & 0.254 & valid \\
\hline SPI5 & 0,970 & 0.254 & valid \\
\hline SPI6 & 0,970 & 0.254 & valid \\
\hline SPI7 & 0,970 & 0.254 & valid \\
\hline SPI8 & 0,947 & 0.254 & valid \\
\hline SPI9 & 0,803 & 0.254 & valid \\
\hline
\end{tabular}

Source: SPSS data, 2021.

Table 3 shows all question items for variable quality financial statement information to have valid criteria. Valid/viable questionnaire items will be used as research instruments, as the $r_{\text {count }}$ is larger when compared to $r_{\text {table. }}$

Table 3. Results of Variable Validity Tests the Quality of Financial Statement Information

\begin{tabular}{|c|c|c|c|}
\hline Question Item & $\mathrm{r}_{\text {count }}$ & $\mathrm{r}_{\text {table }}$ & Information \\
\hline KILP1 & 0,759 & 0.254 & valid \\
\hline KILP2 & 0,880 & 0.254 & valid \\
\hline KILP3 & 0,814 & 0.254 & valid \\
\hline KILP4 & 0,847 & 0.254 & valid \\
\hline KILP5 & 0,843 & 0.254 & valid \\
\hline
\end{tabular}

\begin{tabular}{|c|c|c|c|}
\hline KILP6 & 0,895 & 0.254 & valid \\
\hline KILP7 & 0,798 & 0.254 & valid \\
\hline
\end{tabular}

Source: SPSS data, 2021.

Table 4 describes Crosbach's Alpha value of each question instrument of more than 0.600. So that the overall question used to measure SPI variables is at a good reliable level.

Table 4. SPI Variable Reliability Test Results

\begin{tabular}{|c|c|c|c|}
\hline $\begin{array}{c}\text { Question } \\
\text { Item }\end{array}$ & $\begin{array}{c}\text { Cronbach's } \\
\text { Alpha }\end{array}$ & Constant & Information \\
\hline SPI1 & 0,975 & 0.600 & reliabel \\
\hline SPI2 & 0,974 & 0.600 & reliabel \\
\hline SPI3 & 0,974 & 0.600 & reliabel \\
\hline SPI4 & 0,980 & 0.600 & reliabel \\
\hline SPI5 & 0,973 & 0.600 & reliabel \\
\hline SPI6 & 0,973 & 0.600 & reliabel \\
\hline SPI7 & 0,973 & 0.600 & reliabel \\
\hline SPI8 & 0,974 & 0.600 & reliabel \\
\hline SPI9 & 0,983 & 0.600 & reliabel \\
\hline
\end{tabular}

Source: SPSS data, 2021.

Table 5 can show the results of testing of nine questions used in the financial statement information quality (Y) variable. Crosbach's Alpha is each question instrument over .600. So that the overall question used to measure SPI variables is at a good reliable level.

Table 5. Reliability Test Results Variable Quality of Financial Statement Information

\begin{tabular}{|c|c|c|c|}
\hline $\begin{array}{c}\text { Question } \\
\text { Item }\end{array}$ & $\begin{array}{c}\text { Cronbach's } \\
\text { Alpha }\end{array}$ & Constant & Information \\
\hline KILP1 & 0,925 & 0.600 & reliabel \\
\hline KILP2 & 0,905 & 0.600 & reliabel \\
\hline KILP3 & 0,913 & 0.600 & reliabel \\
\hline KILP4 & 0,910 & 0.600 & reliabel \\
\hline KILP5 & 0,910 & 0.600 & reliabel \\
\hline KILP6 & 0,904 & 0.600 & reliabel \\
\hline KILP7 & 0,917 & 0.600 & reliabel \\
\hline
\end{tabular}

Source: SPSS data, 2021. 


\subsubsection{Hypoheses Test}

The $\mathrm{t}$ test basically shows how far the influence of individually independent variables has on dependent variables. Table 1 is indicated the value of $t_{\text {count }}$ and the degree of significance of variable $\mathrm{X}$, which is an indicator of acceptance and rejection of the hypothesis. The results of hypothesis testing on an independent variable $(X)$ value $t_{\text {count }} 2,346$. The result obtained for the $t_{\text {table }}$ amounted to 2,346 . Because $t_{\text {count }}>t_{\text {table }}(2,346$ $>2.003$ ) with a significant value of 0.023 then the significant value is less than 0.05 or ( $\mathrm{sig}$ ) $0.023<0.05$ so it can be said that the Independent variable SPI (X) has an influence on the variable depending on the quality of financial statement information $(\mathrm{Y})$. This means that it can be concluded that SPI has a significance on the quality of financial statement information.

\subsection{Discussion}

Based on the results of hypothesis testing obtained the value of variable $t_{\text {count }}$ SPI worth 2.346 greater than the value of $t_{\text {table }}$ of 2,003 . With the result of the $t_{\text {count }}$ obtained greater than the value of the $t_{\text {table }}$ so it can be concluded that the SPI variable has a positive effect on the quality of financial statement information. The significance value of SPI is 0.023 < probability of 0.05 . These results show that SPI has a positive and significant effect on the quality of financial statements. This means that the hypothesis is that SPI is accepted and has a positive and significant influence on the quality of financial statement information in the Regional Secretariat of Palembang city.

SPIP is a control system in the central government and local government that is organized thoroughly. SPIP is intended to provide adequate confidence in achieving effectiveness and efficiency. SPIP has several elements for the achievement of state maintenance goals. Improving the quality of state financial management can be done through these SPI elements by taking steps such as strengthening supervision, clear separation of main tasks and functions, delegation of authority, documentation of complete and legitimate transactions, accurate and timely recording and testing of existing internal control systems. To achieve good quality financial statements, these elements must run well. Thus, SPI [5] is the foundation of good governance and the first line of defense against the validity and information in the preparation of financial statements. The better the SPI, the better the quality of financial statement information.

The results of this study are in accordance with [5] [6] which states that SPI has a positive influence on the quality of financial statement information. This research also reinforces [7] [10] that SPI has a positive effect on the quality of financial statement information. The Regional Secretariat of Palembang City has been guided by Government Regulation No. 60 of 2008 [4]. The implementation of the policy of separating responsibility and authority expressly for SPI has worked well. This means that with a good SPI in an organization it will have an impact on improving the quality of financial statement information.

\section{CONCLUSION}

SPI affects the quality of financial statement information at the Regional Secretariat of Palembang City. This means that with a good SPI in an organization it will have an impact on improving the quality of financial statement information. The increase in SPI has an impact on improving the quality of financial statement information at the Regional Secretariat of Palembang city which makes the management of regional finances effective, efficient, transparent, and accountable.

\section{ACKNOWLEDGMENT}

Thankfully acknowledges scientific discussion with our colleagues from State Polytechnic of Sriwijaya, Indonesia. The authors would like to acknowledge the anonymous reviewers at the $5^{\text {th }}$ FIRST 2021 International Conference for the feedback of this paper. Also, thanks to the reviewers who provided feedback as part of this proceeding review process.

\section{REFERENCES}

(1) Suwardjono. (2014). Teori Akuntansi Perekasayasaan Pelaporan Keuangan Edisi Ketiga. Yogyakarta: BPFE Yogyakarta.

(2) Martini, R., Agustin, R., \& Sari, K. R. (2020). Accrual Discretion Policy on Excess/Less Budget Financing at the Provincial Level. TEST Engineering \& Management, 82, 9925-9935.

(3) Sanjaya, I., Martini, R., Ahnaf. M. F. (2021). Fiscal Stress: Growth Aspects of PAD, Growth of Capital Expenditure, and Economic Growth. Atlantis Highlights in Social Sciences, Education and Humanities, volume 1. Proceedings of the 4th Forum in Research, Science, and Technology (FIRST-T3-20). 177 - 183.

(4) Government Regulation No. 60 of 2008 on Internal Government Control System 
(5) Martini, R., Lianto, N., Hartati, S., Zulkifli, Z., \& Widyastuti, E. (2019). Sistem Pengendalian Intern Pemerintah atas Akuntanbilitas Pengelolaan Keuangan Dana Desa di Kecamatan Sembawa. Jurnal Akademi Akuntansi, 2(1), 108. Retrieved from http://ejournal.umm.ac.id/index.php/jaa.

(6) Indra. (2017). Determinasi Kualitas Laporan Keuangan Pemerintah Daerah. Jurnal Ekonomi dan Manajemen 13(1), 1907-3011.

(7) Mahaputra, I. P., \& Wayan, P. I. (2014). Analisis Faktor-faktor yang Mempengaruhi Kualitas Informasi Pelaporan Keunagan Pemerintah Daerah, 8.2, 230-244.
(8) Martini, R., Sari, K. R., Somadi, T., \& Karman, I. W. (2019). Financial Independence of the South Sumatra Regional Government. Proceedings of the International Conference on Applied Science and Technology 2019-Social Sciences Track (iCASTSS 2019). 354, pp. 360-364. Denpasar: Atlantis Press. https://doi.org/10.2991/icastss-19.2019.75.

(9) Government Regulation No. 71 of 2010 on Government Accounting Standart.

(10) Qomah, S., \& Ismunwan. (2021). Faktor-faktor yang Mempengaruhi kualitas Informasi Laporan Keuangan Pemerintah Daerah. Jurnal Akuntansi Trisakti. Vol. 8, 95-108. 